\title{
HUBUNGAN ANTARA HARGA DIRI DENGAN PERILAKU AGRESIF PADA REMAJA SUKU KOMERING DI DESA “X” KABUPATEN OGAN KOMERING ULU TIMUR (OKUT)
}

\author{
Woro Ayu Wigati dan Luh Putu Shanti Kusumaningsih \\ Fakultas Psikologi Universitas Islam Sultan Agung Semarang \\ Email: luhputu@unissula.ac.id
}

\begin{abstract}
Abstrak
Perilaku agresif merupakan tindakan sengaja yang dilakukan oleh seorang individu dengan maksud melukai orang lain secara lisan ataupun nonlisan. Salah satu faktor yang menyebabkan perilaku agresif adalah harga diri. Harga diri merupakan penilaian diri yang terbentuk dari adanya interaksi dimana akan terlihat dari sikap seseorang dalam menerima atau menolak keberadaan dirinya. Penelitian ini bertujuan untuk mengetahui hubungan antara harga diri dengan perilaku agresif pada remaja Suku Komering di desa " $X$ " Kabupaten Ogan Komering Ulu Timur (OKUT). Penelitian ini menggunakan metode kuantitatif. Subjek penelitian berjumlah 130 orang dengan metode purposive sampling. Pengambilan data menggunakan dua skala yaitu skala perilaku agresif dan skala harga diri. Uji hipotesis menggunakan teknik product moment. Hasil uji hipotesis menunjukkan tidak ada hubungan negatif antara harga diri dengan perilaku agresif pada remaja suku komering di desa " $X$ " Kabupaten Ogan Komering Ulu Timur (OKUT) $\left(r_{x y}=0,135\right.$ dengan $\left.p=0,302\right)$.
\end{abstract}

Kata kunci: perilaku agresif, harga diri

\section{RELATIONSHIP BETWEEN SELF-ESTEEM WITH AGGRESSIVE BEHAVIOR IN ADOLESCENT KOMERING TRIBE IN THE VILLAGE “X” DISTRICT OGAN KOMERING ULU TIMUR (OKUT)}

\begin{abstract}
Aggressive behavior is deliberate actions which are performed by an individual withthe intent of injuring another person verbally or non verbal. One of the factors that causes aggressive behavior is self esteem. Selfesteem is a self-assessment that form of interaction which will be visible from someone's attitude in accepting or rejecting the existence of himself. The purpose of this research is to find out the correlation between selfesteem with aggressive behavior in adolescentKomering tribe in the village " $X$ " District Ogan Komering Ulu Timur (OKUT). This research using quantitative method. This research using 130 adolescent as sample research that piked up with puposive sampling. The data in this research were collected by using two scales, aggressive behavior scale and self-esteem scale.The statistical method used to test hypothesis is product moment technique. Hypothesis test result has showed no negative relationship between self-esteem and aggressive behavior in adolescent of komering tribe in village " $X$ " Regency of Ogan Komering Ulu Timur (OKUT) $(r x y=0,135$ with $p=0,302$ ).
\end{abstract}

Keywords: aggressive behavior, self-esteem

\section{Pendahuluan}

Indonesia adalah negara dengan kekayaan yang melimpah, mulai dari suku bangsa, budaya dan bahasa. Budaya-budaya yang beragam di Indonesia antara lain budaya Madura, Dayak, Jawa, Melayu, Sunda, Sasak, Bima, Bugis, Komering dan masih banyak lagi. Perbedaan-perbedaan tersebut seringkali menimbulkan konflik kekerasan diantara masyarakat. Konflik antar Suku terutama 
seringkali menjadi pemicunya seperti, konflik yang pernah terjadi antara suku dayak dan madura yang terjadi pada tahun 2001 dimana menyebabkan banyak korban (Uky, 2016).

Sumatera Selatan adalah salah satu provinsi yangada di Indonesia yang memiliki keragaman budaya dan suku. Suku yang ada di provinsi Sumatera Selatan juga banyak seperti, Suku Melayu Palembang, Suku Melayu Komering, Suku Melayu Semendo, Suku Melayu Empat Lawang, Suku Melayu Musi, Suku Melayu Banyuasin, Suku Jawa, Suku Sunda, Suku Tionghoa, Suku Minangkabau dan masih banyak suku lainnya.

Suku Komering adalah salah suku di Provinsi Sumatera Selatan dimana letak wilayahnya ada di sepanjang sungai Komering. Nama Komering itu sendiri diangkat dari nama Way atau disebut juga sebagai Sungai yang ada di Sumatera Selatan dimana sungai tersebut menunjukkan daerah kekuasaan Komering (Purnamasari, 2012). Masyarakat Suku Komering (jolma kumoring) merupakan penduduk yang gemar melakukan perjalanan sehingga budaya Suku Komering pada saat ini telah menyebar hingga ke daerah Lampung. Suku Komering memiliki beberapa marga seperti, marga Sosoh Buay Rayap, Buay Pemuka Peliyung, marga Buay Madang, dan Semendawai (Pangindoman, 2013). Wilayah terluas di Sumatera Selatan adalah wilayah Komering apabila dibandingkan dengan wilayah budaya suku-suku lainnya yang ada di Sumatra Selatan. Bukan hanya itu, apabila dilihat berdasarkan sifat, Suku Komering dikenal sebagai orang yang keras dan temperamen, namun masyarakat Suku Komering terkenal sebagai

orang-orang agamis. Masyarakat Suku Komering mayoritas beragama Islam (Rifa'i, 2008). Masyarakat Suku Komering memiliki sifat mudah tersinggung dan cenderung mudah marah, sehingga seringkali menimbulkan konflik dalam masyarakat dengan banyaknya kesalahpahaman yang timbul. Konflik-konflik yang muncul menimbulkan penilaian buruk dari masyarakat pada umumnya. Hal ini mengakibatkan masyarakat menghindari hubungan sosial dengan orang-orang dari Suku Komering. Masyarakat akhirnya menilai bahwa Masyarakat Suku Komering adalah orang yang keras, temperamen, egois dan tidak pernah mau mengalah.

Bolman (Dayakisni \& Hudaniah, 2001) menjelaskan bahwa dimulai pada usia 0 - 6 bulan perilaku agresi telah ditunjukkan oleh individu hanya saja perilaku tersebut belum dapat dibedakan secara jelas seperti apa bentuknya. Pada usia 6-14 tahun agresi yang ditimbulkan oleh individu biasanya berupa kemarahan, rasa cemburu, jengkel, dan senang mengkritik. Pada usia 14 tahun dewasa seharusnya seorang individu telah mampu mengontrol emosi dirinya namun, pada kenyataannya masyarakat Suku Komering belum mampu dikarenakan faktor lingkungan. Perilaku agresif itu sendiri menurut Dollard diartikan sebagai suatu tanggapan emosi yang tidak terkendali sehingga muncul perilaku merusak, menyerang, menyakiti dan melukai oranglain, lingkungan bahkan diri sendiri yang biasanya disebabkan oleh frustrasi dan kekecewaan yang mendalam yang sedang dirasakan (Tentama, 2012).

Salah satu contoh perilaku agresif yang dilakukan oleh masyarakat Suku Komering yaitu sering melakukan pembegalan, bahkan ketika seseorang melakukan kesalahan kepada masyarakat Suku Komering, maka dampak konflik tersebut akan berkepanjangan. Suku Komering juga seringkali berkonflik dengan Suku Bali dimana konflik tersebut berkepanjangan hingga saling membunuh satu sama lain. Hal tersebut dapat terlihat ketika masyarakat Suku Bali yang diberhentikan terlebih dahulu ketika akan memasuki daerah sekitar Suku Komering.

Rakhmat (2005) juga telah mengungkapkan bahwa terdapat faktor utama yang menyebabkan munculnya perilaku agresif yaitu harga diri. Maslow menyebutkan harga diri ialah 
salah satu dasar kebutuhan manusia. Kebutuhan harga diri ini meliputi perasaan ingin dihormati, komitmen, rasa ingin diterima, diperhatikan, bersahabat dan bernilai (Kuntaraf \& Kuntaraf, 1999). Harga diri merupakan perkembangan fenomena yang dalam perkembangannya terjadi secara bertahap saling dipengaruhi dan mempengaruhi pengalaman dan perilaku. Harga diri sendiri memiliki dua sumber yang mempengaruhi yaitu sumber internal ( prestasi yang diperoleh sendiri) dan sumber eksternal (afirmasi dari oranglain) (Prihadi \& Chua, 2012).Jika individu memiliki kemampuan untuk menerima diri sendiri dengan apa adanya, maka individu tersebut akan mampu menghargai dirinya dengan baik. Kemampuan untuk bisa menghargai diri sendiri juga sangat tergantung pada kemampuan individu dalam memandang, menganalisa, mengevaluasi dan menilai keberadaan diri sendiri.

Setiap orang tentu akan sangat menjunjung tinggi harga dirinya, sama halnya dengan masyarakat Suku Komering yang menganggap bahwa harga dirinya adalah suatu kehormatan yang tidak boleh direndahkan oleh siapapun. Pada dasarnya harga diri seseorang dapat dilihat dari perilaku orang itu sendiri. seseorang yang memiliki keyakinan yang penuh akan kehormatan dan keberadaan dirinya dapat disebut memiliki harga diri yang tinggi begitu juga sebaliknya, ketika seorang individu tidak memiliki keyakinan akan kehormatan dan keberadaan dirinya maka dapat dikatakan orang tersebut memiliki harga diri yang rendah.

\section{Tinjauan pustaka}

\section{Perilaku Agresif}

Perilaku agresif itu sendiri merupakan suatu tindakan yang dilakukan secara sengaja oleh seorang individu dengan maksud melukai orang lain baik secara verbal maupun non-verbal. Perilaku agresif menurut Dollard diartikan sebagai suatu tanggapan emosi yang tidak terkendali sehingga muncul perilaku merusak, menyerang, menyakiti dan melukai oranglain, lingkungan bahkan diri sendiri yang biasanya disebabkan oleh frustrasi dan kekecewaan yang mendalam yang sedang dirasakan (Tentama, 2012). Bentuk-bentuk perilaku agresif antara lain adalah agresi fisik, agresi verbal, agresi emosi dan agresi dengan tujuan tertentu.

Perilaku agresif menurut Albin memiliki lima aspek (2002), yaitu aspek pertahanan diri, ketegasan, perlawanan disiplin, egosentrisme, dan aspek superioritas. Perilaku agresif disebabkan oleh beberapa faktor yang mempengaruhi yaitu deindividuasi, kepatuhan dan kekuasaan, provokasi serta pengaruh dari alkohol (Sutowo \& Wibisono, 2013). Perilaku agresif juga dapat disebabkan oleh pengaruh keluarga (Sarwono, 2002). Perilaku agresif dapat muncul pada lingkup yang luas bisa di sekolah maupun di lingkungan sekitar rumah. Perilaku agresif ini tentu akan mengganggu dalam kehidupan sosial.

Myers (Sarwono, 2002) mengelompokkan agresi menjadi dua jenis, yaitu: agresi yang dilakukan hanya untuk melampiaskan emosi dan agresi yang hanya digunakan sebagai sarana untuk mencapai tujuan tertentu.

Medinus dan Johnson (Dayakisni \& Hudaniah, 2009) membagi agresi menjadi empat kategori, yaitu:

a. Menyerang secara fisik seperti, menikam, meninju, menendang, meludahi, mendorong, dan merampas.

b. Menyerang kepada obyek yaitu menyerang binatang dan benda mati. 
c. Menyerang dengan lisan seperti, mengancam, menjelek-jelakan orang lain, dan menuntut.

d. Mengambil hak orang lain.

Terdapat tiga faktor yang mempengaruhi perilaku agresi menurut (Sarwono, 2002) yaitu:

a. Kondisi lingkungan seperti, menurut Berkowitz sakit fisik dan sakit psikis dapat memicu perilaku agresi, griffiit juga menyatakan bahwa suhu ekstrim juga dapat menjadi penyebab timbulnya amarah, adanya serangan, rasa sesak berdesak-desakan, kepadatan, pornografi, dan juga televisi.

b. Pengaruh kelompok seperti, menurunkan hambatan dari kendali moral, adanya desakan dari kelompok atau identitas kelompok, deindividuasi, penyalahgunaan alkohol.

c. Pengaruh kepribadian dan kondisi fisik, teori sifat menjelaskan bahwa individu yang memiliki tipe kepribadian A yang bersifat kompetitif, ambisius, tergesa-gesa, mudah tersinggung cenderung lebih cepat menjadi agresif dibandingkan dengan orang dengan tipe kepribadian B yang sudah puas dengan keadaanya, ambisinya tidak tinggi, dan cenderung tidak terburu-buru, selain itu orang yang pemalu cenderung lebih agresif dari pada orang tidak pemalu, orang yang memiliki harga diri yang rendah.

Aspek-aspek perilaku agresif menurut Albin (2002, h. 7), yaitu:

a. Aspek pertahanan diri

Pertahanan diri Yaitu kecenderungan untuk mempertahankan diri dengan cara menunjukkan permusuhanan atau pemberontakan.

b. Aspek ketegasan

Ketegasan yaitu individu berani untuk menentukan sikap apabila dihadapkan pada suatu permasalahan yang menuntut untuk pengambilan keputusan dengan segera.

C. Aspek perlawanan disiplin

Perlawanan disiplin yaitu individu melakukan hal yang menyenangkan namun cenderung melanggar peraturan.

d. Aspek egosentrisme

Egosentrisme yaitu mengutamakan kepentingan pribadi tanpa memperhatikan orang lain.

e. Aspek superioritas

Superioritas yaitu individu merasa paling baik dibandingkan dengan oranglain.

\section{Harga Diri}

Harga diri menurut Coopersmith (Widodo \& Pratitis, 2012) yaitu suatu evaluasi diri baik yang positif maupun yang negatif. Chaplin (2004) mengartikan harga diri merupakan suatu penilaian terhadap diri sendiri yang dipengaruhi oleh berbagai faktor seperti, sikap, interaksi, penghargaan, dan penerimaan orang lain terhadap individu. Santrock (2002) mengartikan bahwa harga diri merupakan nilai diri atau citra diri seseorang. Aspek harga diri menurut Coopersmith (Hudaniah dan Dayakisni, 2003) yaitu power, significance, virtue, dan competence. Sedangkan Burn (Widodo \& Pratitis, 2012) menjelaskan bahwa ada dua aspek harga diri, yaitu: evaluasi diri (self- evaluation), yang mengacu pada pembuatan penilaian terkait pentingnya diri, dan keberhargaan diri (self-worth), yaitu perasaan bahwa dirinya berharga. Coopersmith (Saputri, 2016) menjelaskan bahwa ada tiga ciri-ciri harga diri yaitu, harga diri yang tinggi, menunjukkan kemampuan dalam menghadapi orang lain ataupun tugas dengan dilandasi harapan untuk sukses dan diterima, harga diri tingkat menengah digambarkan sebagai seseorang yang memiliki kepercayaan diri yang agak lemah dan harga diri yang rendah rendah digambarkan sebagai orang yang tidak percaya pada dunia, disamping tidak adanya 169 P-ISSN 1907-8455 
kepercayaan dan penghargaan terhadap dirinya sendiri. Coopersmith (Hudaniah dan Dayakisni, 2003)mengungkapkan bahwa ada 4 aspek harga diri yaitu:

a. Power, merupakan kemampuan yang dimiliki seseorang dalam mengendalikan diri atau bahkan mempengaruhi orang lain.

b. Significance, merupakan penerimaan dalam diri yang dipengaruhi oleh penilaian oranglain terhadap dirinya.

c. Virtue, merupakan ketaatan seseorang terhadap aturan dan norma yang ada di masyarakat.

d. Competence, merupakan kemampuan seseorang untuk berhasil meraih sesuatu sesuai dengan tujuan yang dimiliki.

Coopersmith (Saputri, 2016) juga menjelaskan bahwa ada tiga ciri-ciri harga diri yaitu:

a. Harga diri yang tinggi, menerangkan bahwa kemampuan ketika menjumpai orang lain ataupun tugas dilandasi dengan harapan untuk sukses dan diterima.

b. Harga diri tingkat menengah, digambarkan sebagai seseorang dengan kepercayaan diri yang agak lemah.

c. Harga diri yang rendah, digambarkan sebagai individu yang tidak memiliki kepercayaan baik terhadap diri sendiri maupun terhadap dunia.

\section{Remaja}

Remaja (Adolensence) yang artinya tumbuh menjadi dewasa, mencakup kematangan mental, sosial emosional dan fisik (Hurlock, 1999). Santrock (2003) menjelaskan bahwa masa remaja adalah masa dimana terjadi perubahan dari anak- anak ke masa dewasa dan di tandai dengan perubahan tubuh, kedewasaan, berpikir,emosi, kemampuan sosialisasi. Masa remaja adalah masa dimana individu sudah mampu berfikir secara abstrak dan mengembangakan pemikiran yang ilmiah. Masa ini disebut juga masa pencarian identitas, termasuk mengembangkan diri (Papalia, Olds, \& Feldman, 2009). Erikson (Santrock, 2003) menyatakan bahwa masa remaja termasuk dalam fase identity vs role diffusion. Fase ini merupakan fase dimana remaja mencari identitas dirinya. Apabila remaja berada dalam lingkungan yang baik maka akan tercipta indentitas yang baik. Begitupun ketika remaja berada di lingkungan yang salah maka akan terjadi kekacauan identitas.

\section{Metode}

Metode pengumpulan data yang digunakan dalam penelitian ini adalah dengan menggunakan skala. Skala dalam penelitian ini terdiri dari aitem favourable dan unfavourable. Penelitian ini menggunakan dua skala yaitu, skala perilaku agresif dan skala harga diri. Skala perilaku agresif terdiri dari 13 aitem yang disusun berdasarkan aspek-aspek pertahanan diri, ketegasan, perlawanan disiplin, egosentrisme, dan superioritas (Albin, 2002). Skala harga diri terdiri dari 12 aitem yang disusun berdasarkan aspek power, significance, virtue, dan competence (Dayakisni dan Hudaniah, 2003). 
Metode pengambilan sampel merupakan suatu cara/teknik yang dipakai untuk mengambil sampel (Hadi, 2001). Sampel penelitian tidak diambil secara acak (non random). Penelitian ini menggunakan teknik pengambilan sampel (sampling) yaitu purposive sampling. Purposive sampling, yaitu pengambilan sampel yang dilakukan menurut ciri atau sifat sesuai dengan tujuan tertentu (Hadi, 2001). Pada penelitian ini ciri yang diperlukan adalah remaja Suku Komering di Desa " $X$ " dengan usia 17-20 tahun.

Uji daya beda aitem menggunakan teknik korelasi Product Moment yang dikembangkan oleh Karl Pearson. Penelitian ini untuk mengetahui koefisien reliabilitas menggunakan koefisien reliabilitas Alpha dari Cronbach. Teknik analisis data yang digunakan dalam penelitian ini menggunakan analisis regresi. Perhitungan statistik dalam penelitian ini menggunakan bantuan SPSS (Statistical Packages for Social Sciences) versi 20.

\section{Uji Daya Beda dan Uji Reliabilitas Alat Ukur}

\section{1) Skala perilaku agresif}

Pada uji coba yang dilakukan terhadap 70 orang, untuk skala perilaku agresif terdiri dari 30 aitem dan hanya 13 aitem yang dianggap memuaskan. Adapun koefisien korelasi aitem totalnya $\left(r_{i x}\right)$ berkisar antara 0,25-0,499. Untuk mengetahui aitem yang terpakai dan aitem yang gugur pada skala perilaku agresif, dapat dilihat pada tabel 5 berikut ini

Tabel 1. Sebaran Nomor Aitem Tryout Berdaya Beda Tinggi dan Rendah Perilaku Agresif

\begin{tabular}{lllccc}
\hline \multirow{2}{*}{ No } & \multirow{2}{*}{ Aspek } & \multicolumn{2}{c}{ Jumlah Aitem } & \multicolumn{2}{c}{ Daya Beda } \\
\cline { 3 - 6 } & & Favourable & Unfavourable & Tinggi & Rendah \\
\hline 1. & Pertahanan Diri & $1,11,18$ & $6^{*}, 14^{*}, 22$ & 4 & 2 \\
2. & Ketegasan & $2,27^{*}, 19$ & $7^{*}, 15^{*}, 23^{*}$ & 2 & 4 \\
& Perlawanan & $3^{*}, 12,20$ & $8^{*}, 29^{*}, 24$ & 3 & 3 \\
3. & Disiplin & & & & \\
4. & Egosentrisme & $4,28,30^{*}$ & $9^{*}, 16^{*}, 25^{*}$ & 2 & 4 \\
5. & Superioritas & $5,{ }^{*} 13,21$ & $10^{*}, 17^{*}, 26^{*}$ & 2 & 4 \\
\hline & & & \multicolumn{2}{c}{$\mathbf{1 3}$} & $\mathbf{1 7}$ \\
\hline
\end{tabular}

Keterangan :

$\left({ }^{*}\right)$ : Aitem gugur atauaitem yang mempunyai daya beda aitem rendah. Berdasarkan uji reliabilitas terhadap skala perilaku agresif diperoleh koefisien Alpha sebesar 0,594.

\section{2) Skala harga diri}

Pada uji coba yang dilakukan terhadap 70 orang, untuk skala perilaku harga diri terdiri dari 28 aitem dan hanya 12 aitem yang dianggap memuaskan. Adapun koefisien korelasi aitem totalnya $\left(r_{i x}\right)$ berkisar antara $0,25-0,541$. Untuk mengetahui aitem yang terpakai dan aitem yang gugur pada skala harga diri, dapat dilihat pada tabel berikut ini: 
Tabel 2. Sebaran Nomor Aitem Tryout Berdaya Beda Tinggi dan Rendah Harga Diri

\begin{tabular}{|c|c|c|c|c|c|}
\hline \multirow{2}{*}{ No } & \multirow{2}{*}{ Aspek } & \multicolumn{2}{|c|}{ Jumlah Aitem } & \multicolumn{2}{|c|}{ Daya Beda } \\
\hline & & Favourable & Unfavourable & Tinggi & Rendah \\
\hline 1. & Power & $1 *, 9 *, 17$ & $5^{*}, 13,21$ & 3 & 3 \\
\hline \multirow[t]{2}{*}{2.} & Significance & $2^{*}, 10,18^{*}$ & $6^{*}, 14^{*}, 22^{*}$ & 2 & 6 \\
\hline & & 25 & $27^{*}$ & & \\
\hline 3. & Virtue & $3,11,19$ & $7^{*}, 15^{*}, 23^{*}$ & 3 & 3 \\
\hline \multirow[t]{3}{*}{4.} & Competence & $4,12,20,26^{*}$ & $8^{*}, 16^{*}, 24^{*}$ & 4 & 4 \\
\hline & & & 28 & & \\
\hline & Total & & & 12 & 16 \\
\hline
\end{tabular}

Keterangan :

$(*)$ : Aitem gugur atauaitem yang mempunyai daya beda aitem rendah. Berdasarkan uji reliabilitas terhadap skala perilaku agresif diperoleh koefisien Alpha sebesar 0,613.

Hasil

Tabel 3. Uji normalitas

\begin{tabular}{|c|c|c|c|c|c|c|}
\hline Variabel & Mean & $\begin{array}{c}\text { Std. } \\
\text { Deviasi }\end{array}$ & K-SZ & Sig. & $\mathbf{P}$ & Keterangan \\
\hline Perilaku & 27,57 & 5,289 & 0,702 & 0,707 & $>0,05$ & Normal \\
\hline \multicolumn{7}{|l|}{ Agresif } \\
\hline Harga Diri & 38,23 & 4,236 & 0,446 & 0,446 & $>0,05$ & Normal \\
\hline
\end{tabular}

Uji hipotesis antara harga diri dengan perilaku agresif diperoleh $r=0,135$ dengan taraf signifikansi $0,302(p>0,05)$. Hasil tersebut menunjukkan bahwa tidak ada hubungan antara harga diri dengan perilaku agresif.

\section{Pembahasan}

Tujuan penelitian ini adalah untuk mengetahui secara empiris hubungan negatif antara harga diri dengan perilaku agresif pada remaja Suku Komering di Desa " $X$ " Kabupaten Ogan Komering Ulu Timur (OKUT). Hasil analisis product moment menunjukkan bahwa hasil uji hipotesis yang diajukan ditolak, yaitu tidak ada hubungan negatif antara harga diri dengan perilaku agresif pada remaja Suku Komering di Desa " $X$ " Kabupaten Ogan Komering Ulu Timur (OKUT). Hal ini berarti, harga diri seseorang tidak mempengaruhi seseorang melakukan perilaku agresif.

Hasil penelitian ini sama dengan penelitian yang dilakukan oleh (Makbul, 2015) dalam skripsinya yang berjudul " SIRI' sebagai Mediator Hubungan Harga Diri (self Esteem) dengan Perilaku Agresif pada Suku Bugis". Penelitian tersebut menyatakan hasil analisis product moment yang memperoleh nilai koefisien korelasi sebesar $=-0,068 ; p=0,206(p>0,05)$ artinya tidak terdapat hubungan signifikan antara harga diri dengan perilaku agresif. 
Menurut Kerlinger (Purnama , Arjanggi, \& Setiowati, 2013) terdapat beberapa sebab yang membuat suatu hipotesis ditolak yaitu:

1. Teori dan hipotesis yang salah

2. Metode yang tidak tepat atau tidak benar

3. Pengukuran yang tidak adekuat atau pengukuran yang ceroboh

4. Analisis yang salah.

Hadi (2001) menjelaskan jika analisis regresi tidak menemukan korelasi atau korelasinya sangat rendah, hal tersebut terjadi karena:

1. Variabel $X$ dan $Y$ memang benar-benar tidak ada korelasinya atau korelasinya sangat rendah.

2. Variabel $X$ dan $Y$ sebenarnya terdapat korelasi yang signifikan tetapi karena datanya tidak linear dan menggunakan program regresi linear, maka korelasi yang dilaporkan sangat underestimated atau signifikan.

Berkaitan dengan hal tersebut diatas, meskipun dalam penelitian ini tidak memakai teknik analisis statistik regresi untuk menguji hipotesisnya, akan tetapi peneliti menggunakan analisis product moment yang juga mensyaratkan uji asumsi yang sama dengan analisis regresi (Anareg) yaitu adanya uji normalitas dan uji linearitas. Pada penelitian ini setelah dilakukan uji linearitas ternyata data yang diperoleh tidak linear. Menurut (Alsa, 2001) jika asumsi-asumsi tidak terpenuhi maka dapat ditempuh langkah-langkah alternatif sebagai berikut: 1) menginterpretasi secara hati-hati hasil analisisnya dan 2) memikirkan kemungkinan transformasi terhadap recalcitrants data. Dengan menggunakan satu atau lebih cara transformasi data yang ada dapat membuat data lebih dapat dipertanggungjawabkan untuk menarik kesimpulan.

Tidak terbuktinya hipotesis, ada kemungkinan dikarenakan konsep dasar yang melandasi hubungan antara harga diri dan perilaku agresif pada remaja sebagaimana telah dikemukakan sebelumnya tidak dapat diartikan sebagai konsep mengenai hubungan langsung antara dua variabel tersebut. Hal ini dapat disebabkan karena tidak adanya kaitan antara harga diri dan perilaku agresif remaja atau karena kaitannya tidak cukup berarti bila dibandingkan dengan faktor- faktor atau variabel-variabel lain yang lebih menentukan terjadi perilaku agresif pada remaja dan harga diri. Faktor-faktor tersebut dapat berupa variabel bebas lainnya yang memiliki pengaruh secara langsung terhadap perilaku agresif pada remaja dan harga diri secara terpisah.

Pada sisi lain, penyebab tidak adanya hubungan antara perilaku agresif remaja dan harga diri mungkin saja disebabkan karena pengaruh dari karakteristik khusus dari subjek yang dijadikan sebagai sampel dalam penelitian ini, yaitu remaja Suku Komering. Remaja Suku Komering sekarang telah banyak yang menempuh pendidikan sehingga lebih mampu mengontrol setiap emosinya, selain itu, remaja cenderung melakukan perilaku agresif tidak berdasarkan harga diri. Pada masa remaja disebut juga sebagai periode "badai dan tekanan", dimana pada masa ini emosi remaja meningkat, tidak terkendali dan cenderung irasional (Hurlock, 1999).

Remaja berasal dari bahasa latin Adolensence yang berarti bahwa tumbuh menjadi dewasa. Adolensence sendiri memiliki arti yang relatif luas mencakup kematangan mental, sosial emosional dan fisik Remaja berasal dari bahasa latin Adolensence yang artinya tumbuh menjadi dewasa. Adelensence mempunyai arti yang luas yang mencakup kematangan mental, sosial emosional dan fisik (Hurlock, 1999). Masa remaja memiliki ciri-ciri antara lain, masa remaja merupakan periode penting, masa peralihan, perubahan, masa remaja juga usia bermasalah, masa untuk mencari identitas, masa yang menimbulkan ketakutan, masa tidak realistik, dan masa menuju dewasa. 
Temuan dari hasil survey awal penelitian di Desa " $X$ " Kabupaten Ogan Komering Ulu Timur (OKUT) menunjukkan bahwa para remaja melakukan perilaku agresif seperti memaki dan memukul orang lain dikarenakan tidak ingin harga diri mereka di rendahkan, akan tetapi dari hasil penelitian diketahui bahwa harga diri tidak mempengaruhi terjadinya perilaku agresif. Faktor yang menyebabkan adanya perbedaan antara data awal dengan hasil penelitian disebabkan karena dalam sampel atau subjek dari survey awal kurang representatif. Peneliti hanya mewawancarai beberapa remaja saja sehingga kurang dapat memberikan gambaran umum mengenai kondisi real dari para remaja di desa " $X$ " Kabupaten Ogan Komering Ulu Timur (OKUT) secara keseluruhan.

\section{Kesimpulan}

Hasil penelitian dan analisis data menunjukkan bahwa tidak ada hubungan negatif antara harga diri dengan perilaku agresif. Hal ini berarti harga diri pada seseorang tidak mempengaruhi seseorang untuk melakukan perilaku agresif.

\section{Saran}

Berdasarkan hasil penelitian, pembahasan dan kesimpulan yang telah diperoleh, maka peneliti mengajukan saran bagi peneliti selanjutnya yang tertarik melakukan penelitian serupa sebaiknya menambahkan variabel lain. Selain itu, dapat pula mengganti subjek penelitian dengan mengambil subjek orang dewasa.

\section{DAFTAR PUSTAKA}

Albin, R. S. (2002). Emosi Bagaimana Mengenal, Menerima dan Mengarahkan. Yogyakarta : Kanisius.

Alsa, A. (2001). Kontroversi Uji Asumsi dalam Statistik Parametrik. Buletin Psikologi, $18-22$.

Azwar, S. (2003). Penyusunan Skala Psikologi. Yogyakarta: Pustaka Pelajar.

Azwar, S. (2009). Reliabilitas dan Validitas. Yogyakarta: Pustaka Offset.

Azwar, S. (2012). Penyusunan Skala Psikologi. Yogyakarta: Pustaka Pelajar.

Baron dan Byrne. (2005). Psikologi Sosial jilid 2. Alih Bahasa: Ratna Djuwita.

Jakarta: Erlangga.

Cast, Alicia D dan Peter J. Burker. (2002): A Teory of Self-Esteem. Jurnal: The University of Nort Carolina Press.

Chaplin. (2004). Kamus Lengkap Psikologi. Alih Bahasa: Kartini Kartono. Jakarta: PT. Raja Grafindo Persada.

Dayakisni, T., \& Hudaniah. (2001). Psikologi Sosial. Malang: Universitas Muhammadiyah Malang.

Donnellan, M. B., Trzesniewski, K. H., Robins, R. w., Moffitt, T. E., \& Caspi, A. (2005). Low Self-Esteem Is Related to Aggression, Antisocial Behavior, and Deliquency. Psychological Science , 328-335, Vol. 16, No. 4.

Esteem, N. A. (2016). Our Definition of Self- Esteem. Retrieved from National Assosiation for Self Esteem: http://healthyselfesteem.org/about-self- esteem/ Hadi, S. (2001). Metodologi Research Jilid 1. Yogyakarta: Andi Offset. 
Hasiolan, M. I. (2014). Hubungan Dukungan Emosional Keluarga dengan Harga Diri Remaja Panti Sosial Karya Wanita Sidoarum. Skripsi. Fakultas Kedokteran dan IImu Kesehatan Universitas Muhammadiyah Yogyakarta, 1-9.

Hurlock, E. B. (1999). Psikologi Perkembangan Suatu Pendekatan Sepanjang Rentang Kehidupan, Alih Bahasa: Istiwidayanti, Suedjarwo. Jakarta: Erlangga.

Kamila, I. I. (2013). Perbedaan Harga Diri (Self Esteem) Remaja ditinjau dari Keberadaan Ayah. Jurnal Psikologi, Vol. 9, No. 2, 100-112.

Kartono, K. (2005). Patologi Sosial II Kenakalan Remaja. Jakarta: PT. Raja Grafindo Persada.

Koeswara, E. (1991). Teori-teori Kepribadian. Bandung: Eresco.

Kuntaraf, k. H., \& Kuntaraf, J. (1999). Komunikasi Keluarga: Kunci Kebahagiaan Anda. Bandung: Indonesia Publishing House.

Makbul, C. (2015). Siri' Sebagai Mediator Hubungan Harga Diri (Self Esteem) dengan Perilaku Agresif pada Suku Bugis.Doctoral dissertation. Universitas Islam Negeri Sultan Syarif Kasim Riau.

Nisfiannoor, M., \& Yulianti, E. (2005). Perbandingan Perilaku Agresif antara Remaja uang Berasal dari Keluarga Bercerai dengan Keluarga Utuh. Jurnal Psikologi Vol. 3 No. 1, 1-18\.

Pangindoman, B. R. (2013, Februari 2). Retrieved from https://bakasrasuanpangindoman.wordpress.com/2013/02/02/sejarah-sukukomering-dan-adat-istiadatnya/

Papalia, E. D., Olds, S. W., \& Feldman, R. D. (2009). Human Development, Alih bahasa: Marswendy B. Jakarta: Salemba Humanika.

Prihadi, K., \& Chua, M. (2012). Student's Self-Esteem at School. Journal of Education and Learning, 1-14.

Purnama , A., Arjanggi, R., \& Setiowati, E. A. (2013). Pengaruh Pelatihan Asertif dalam Meningkatkan Perilaku Asertif Remaja Perokok Pasif. Jurnal Psikologi Proyeksi, 47-62.

$\begin{array}{lllll}\text { Purnamasari, } & \text { O. M. } & \text { (2012, Juli } & \text { Retrieved }\end{array}$ from https://octameliapurnamasari.wordpress.com/2012/07/21/suku-komeringadalah-orang-lampung-juga/

Puspitasari, N., \& Indrawati, E. S. (2014). Hubungan antara Harga Diri dengan Intensi Agresi pada Anggota SAT DALMAS di POLRES Semarang. Empati Fakultas Psikologi, 169-185.

Rakhmat, J. (2005). Psikologi Komunikasi. Bandung: Remaja Rosdakarya.

Restu, Y., \& Yusri. (2013). Studi tentang Perilaku Agresif Siswa di Sekolah. Jurnal IImiah Konseling, 243-249.

Rifa'i, A. (2008, Mei 21). Kepribadian Seseorang. Retrieved from Acmadrif.blogspot.co.id: http://acmadrif.blogspot.co.id/2008/05/harga- diriadalah-harga-mati-yang-harus.html

Santrock, John W. (2002). Life-Span Development: Perkembangan Masa Hidup, Edisi ketigabelas, Jilid I. Alih Bahasa: Benedictine Widyastutu. Jakarta: Erlangga. 
Saputri, H. R. (2016). Hubungan antara Fashion Involvement dan Impulsive Buying dengan Harga Diri (Self Esteem) pada Remaja di SMAN 2 Samarinda. eJournal Psikologi, Vol. 4, No. 2, 240-250.

Sarwono, S. W. (1999). Psikologi Sosial. Jakarta: Balai Pustaka.

Sarwono, S. W. (2002). Psikologi Sosial: Psikologi Kelompok dan Psikologi Terapan. Jakarta: Balai Pustaka.

Sears, David O, Jonathan B. Freedman dan L. Anne Peplau. 1985. Psikologi Sosial. Alih Bahasa: Michael Adryanto. Jakarta: Erlangga.

Shaheen, D. F., \& Jahan, D. M. (2014). Role of Self Esteem in Development of Aggresive Behavior Among Adolescents. International Journal of Education and Psychological Research (IJEPR), hal 54-57, Vol. 3, No. 4.

Siddiqah, L. (Juni 2010). Pencegahan dan Penanganan Perilaku Agresif Melalui Pengelolaan Amarah (Anger Management). Jurnal Psikologi, Volume 37, NO.1 hal. 50-64.

Srisayekti, W., Setyadi, D. A., \& Sanitioso, R. B. (2015). Harga Diri (Self- esteem) Terancam dan Perilaku Menghindar. Jurnal Psikologi Vol. 42, No. 2., 141-156.

Sugiyono. (2009). Metode Penelitian Kuantitatif dan R\&D. Bandung: Alfabeta. Sutowo,

I., \& Wibisono, S. (2013). Perilaku Agresif Anggota Organisasi

Kemasyarakatan (ORMAS) "X" di Provinsi D.I.Yogyakarta. Jurnal

Humanitas, 31-44, Vol.X, No.2.

Tentama, F. (2012). Perilaku Anak Agresif: Asesmen dan Intervensinya. Jurnal KESMAS, 162-232.

Uky. (2016, Februari 25). Lima Konflik SARA Paling Mengerikan Ini Pernah Terjadi di

$$
\text { Indonesia. Retrieved from }
$$

Okezone:

https://news.okezone.com/read/2016/02/25/340/1320731/lima-konflik- sara-palingmengerikan-ini-pernah-terjadi-di-indonesia

Widodo, A. S., \& Pratitis, N. T. (2013). Harga Diri dan Interaksi Sosial ditinjau dari Status Sosial Ekonomi Orang Tua. Jurnal Psikologi Indonesia, hal. 131-138, vol.2, No.2. 